\title{
ENVIRONMENTAL ENGINEERING
}

\section{Test Reference Year of Riga, Latvia}

\author{
Mārtiņš Ruduks, Arturs Lešinskis, Latvia University of Agriculture
}

\begin{abstract}
Increasing global demand for energy resources leads to actions that optimize the usage of these resources. To make actual and reliable calculations for energy usage and to be able to determine the optimal heating systems, it is necessary to know the latest climate conditions in the area. One of the methods to determine the climate conditions is to generate a test reference year (TRY) for this area. In this paper the TRY of Riga, the capital city of Latvia, was generated by applying the standard LVS EN ISO 15927-4. To generate TRY, four parameters were used: temperature, relative humidity, cloud coverage and wind velocity. The Latvian Environment Geology and Meteorology Centre (LEGMC) provided the meteorological data used in this research. TRY was generated by analyzing meteorological data for thirty-year period (1984-2013) in Riga. The results were compared with the data from Latvian Building Code LBN 003-15, and it showed a deviation in average temperature values that can be explained by the climate change in this area.
\end{abstract}

Keywords: test reference year, building energy simulations, climate change

\section{Introduction}

There are different possibilities how to determine the latest climate conditions in the particular area. Two most popular methods are test reference year (TRY) and typical meteorological year (TMY). Both methods are similar and are based on Halls et. al. [3] described method with a difference that TMY method uses weighting factors for climate parameter assessment, where TRY uses all parameters at equal base. The use of TRY method is described in LVS EN ISO 15927-4 [5]. Both models consist of 8760-hour measurements of meteorological parameters that correspond with average meteorological parameter values for selected period [10]. Both models have been used in various research [1-3, 7-12]

In Latvia there have been research for TRY creation for Riga [7, 12], but the authors' research for
Riga and their previous research for Liepaja [8] and Aluksne [9] are the first ones that analyses 30 year meteorological data for climate model creation.

Meteorological data provided for the research were gathered from meteorological station in Riga, which is located: latitude $56^{\circ} 57^{\prime} 02.16^{\prime \prime}$, longitude $24^{\circ} 066^{\prime} 57.86^{\prime \prime}$. It is elevated $6.15 \mathrm{~m}$ above the sea level. It is located in the middle part of Latvia (Figure 1). Meteorological data were obtained from Latvian Environment Geology and Meteorology Centre (LEGMC) for 30-year period (1984-2013). LEGMC provides meteorological elements with 3-hour interval; the necessary hourly values were interpolated.

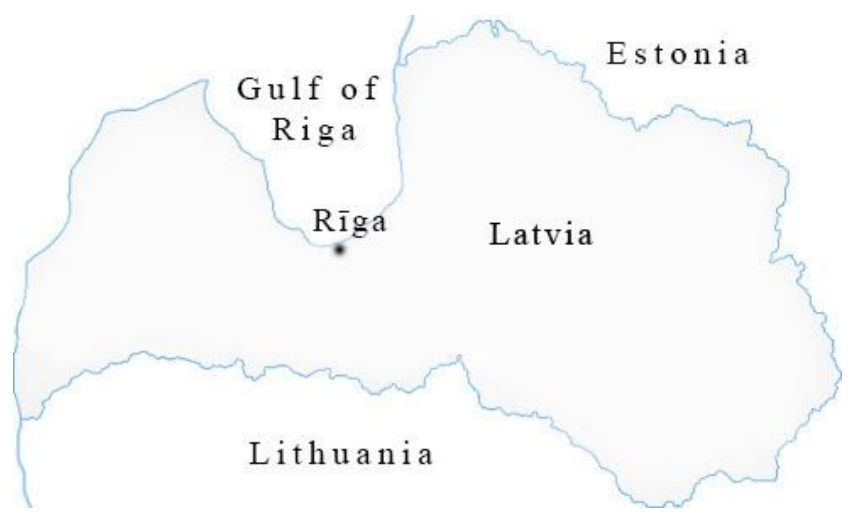

Fig. 1. Illustration of territory of Latvia (Created by authors using border of Latvia [4])

Latvian Building Code LBN 003-15 [6] represents climate conditions in Latvia, but data were generated by analyzing meteorological conditions for the period of 1961-1990. Climate data provided by
LBN 003-15 do not represent the actual climate situation and only monthly average values for temperature and relative humidity are provided, but many detailed building energy simulations for 
heating ventilation and air conditioning (HVAC) systems require hourly climate values.

The aim of this research is to generate climate database (TRY) for Riga that would contain more recent hourly climate data that could be used in future research for HVAC devices.

\section{Methodology}

In this research, to generate TRY of Riga, LVS EN ISO 15927-4 [5] described method was applied. To generate TRY, four meteorological parameters were taken into account: dry-bulb air temperature, relative humidity, cloud coverage (LVS EN ISO 15927-4 describes to use direct normal irradiance at cloud coverage place, but at this meteorological station there are no data for this parameter, so it was replaced with cloud coverage) and wind speed. The first three parameters are key parameters, but wind speed is secondary parameter.

Meteorological parameter values were provided by the Latvian Environment Geology and Meteorology Centre (LEGMC). LEGMC provided meteorological parameters with 3-hour interval. LVS EN ISO 15927-4 suggests using hourly meteorological parameter values, so the missing values were generated by linear interpolation. TRY creation process requires to analyze at least 10 years of meteorological parameters [5]. In this research 30year meteorological data were used for the time period 1984-2013.

To be able to compare all 30-year meteorological data equally, 29 February was excluded from this process, therefore TRY consists of 8,760 hourly meteorological parameter values.

The daily mean value was calculated for key parameters $\mathrm{p}$ (dry-bulb air temperature, relative humidity and cloud coverage). The cumulative distribution function, $\Phi_{\mathrm{p}, \mathrm{mi}}$, of daily means (through 30 years) was calculated for each calendar month $\mathrm{m}$, using equation (1) [5]

$$
\Phi_{p, m, i}=\frac{K_{i}}{N+1}
$$

where:

$\mathrm{K}_{\mathrm{i}}$ is the rank order of the $\mathrm{i}$-th value of the daily means within that calendar month in the whole data set;

$\mathrm{N}$ is the number of days in calendar month.

The cumulative distribution function, $F_{p, y, m, i}$, of the daily means within each calendar month, for each year y, (through 30 years) was calculated using equation (2) [5]

$$
F_{p, y, m, i}=\frac{J_{i}}{n+1}
$$

where:
$J_{i}$ is the rank order of the i-th value of the daily means within that calendar month (that year);

$\mathrm{N}$ is the number of days in observed month.

For each calendar month the Finkelstein-Schafer (FS) statistic, $F S_{p, y, m}$, was calculated for each year of the data set using equation (3) [5]

$$
F S_{p, y, m}=\sum_{i=1}^{n}\left|F_{p, y, m, i}-\Phi_{p, m, i}\right|
$$

Finkelstein-Schafer statistic, $F S_{p, y, m}$, was calculated for key parameters (dry-bulb air temperature, cloud coverage and relative humidity) and each parameter value was ranked in increasing order of $F S_{p, y, m}$.for each calendar month in multiyear record.

For each calendar month, individual months from 30-year record were ranked in order of increasing size of $F S_{p, y, m}$ for all key parameters.

All three separate parameter ranks were added together and ranked in increasing size of total rank number for each calendar month each year. Three months with the lowest total ranking for each calendar month were selected for the second stage (candidate months).

In the second stage, monthly mean values of the wind speed were calculated for all three candidate months for each calendar month. The month that had the closest average wind speed value to the corresponding multi-year calendar month mean was selected as the typical meteorological month (TMM) to be included in the test reference year.

When all twelve TMM were selected to be included in TRY, some adjustments were made - for each climate parameter the last eight hours of each month and the first eight hours of the next month were smoothened to make a smooth transition of values or different TMM. The same adjustment was made for the last eight hours of December and the first eight hours of January to use TRY for repeated simulations [5].

\section{Results and discussion}

According to the described methodology, TRY was created for Riga, the capital city of Latvia. The year form which calendar months were included in TRY is shown in Table 1. The results show that two calendar months were selected from 1993 (April and October), and two calendar months were selected from 2008 (January and November), the remaining calendar months were selected from different years. The results show that TMM were selected from a large period and there is no one particular year that has the best match for 30-year average values.

The comparison of the selected calendar months for Riga with Pauls' research results [7] that was 
made for the ten-year period (2001 - 2010) shows one calendar month that was selected from the same year, i.e., 2001 (February). Although TRY selection period is different (30 year over 10 year), February from 2001 is the best match for both periods.

TABLE 1

Selected months for TRY generation [Source: the authors' construction]

\begin{tabular}{|c|c|c|c|c|c|c|}
\hline Month & Jan & Feb & Mar & Apr & May & Jun \\
\hline Year selected for TRY & 2008 & 2001 & 1999 & 1993 & 1998 & 2000 \\
\hline Month & Jul & Aug & Sep & Oct & Nov & Dec \\
\hline Year selected for TRY & 2009 & 2011 & 1995 & 1993 & 2008 & 1987 \\
\hline
\end{tabular}

In TMM selection process 30 different months were analyzed; Figure 2 show the cumulative percentage comparison for temperature of December with best (1989) and worst (2006) FS statistics, when the long-term temperature results were compared with the corresponding month temperature. A curve with triangles represents daily average temperature values from year 1989. This month is included in TRY when all four parameters are taken into account. Temperature values for TRY model reveal high similarity with 30-year average data.

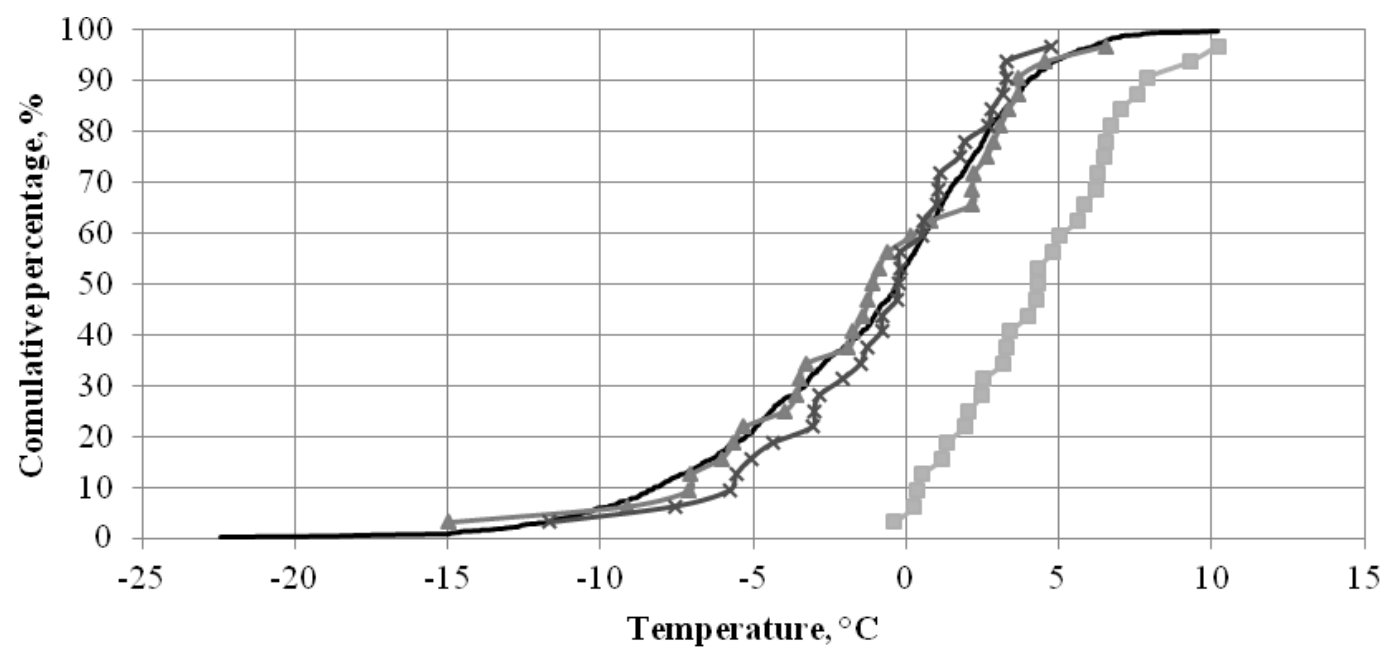

$\longrightarrow 30$ year data - -Worst FS (2006) $\longrightarrow$ Best FS (1989) $\longrightarrow$ Final selection (1987)

Fig. 2. Comparison of temperature cumulative percentage for December

When all TMM are selected and united, it is possible to compare the average daily temperature values for TRY model with 30-year average data (the results are compared in Figure 3). TRY model values reveal high similarity with 30 -year data. There is a difference in the temperature cumulative percentage until $30 \%$ mark, when TRY model shows little higher temperature values, but other values are very similar.

When TRY is created, there are 8,760 hourly values of meteorological elements from January till
December. The air temperature variation over the year period is shown in Figure 4. The maximum value of the air temperature observed in TRY is $+30.1{ }^{\circ} \mathrm{C}$, the minimum $-18.7^{\circ} \mathrm{C}$ and average is $7.5^{\circ} \mathrm{C}$.

When 30-year average air temperature values were compared for the period of 1984-2013 (Figure $5)$, they showed the increase in air temperature values. The average air temperature has increased from $6.5{ }^{\circ} \mathrm{C}$ to $7.9{ }^{\circ} \mathrm{C}$, which is $21.5 \%$ increase in average air temperature value. 


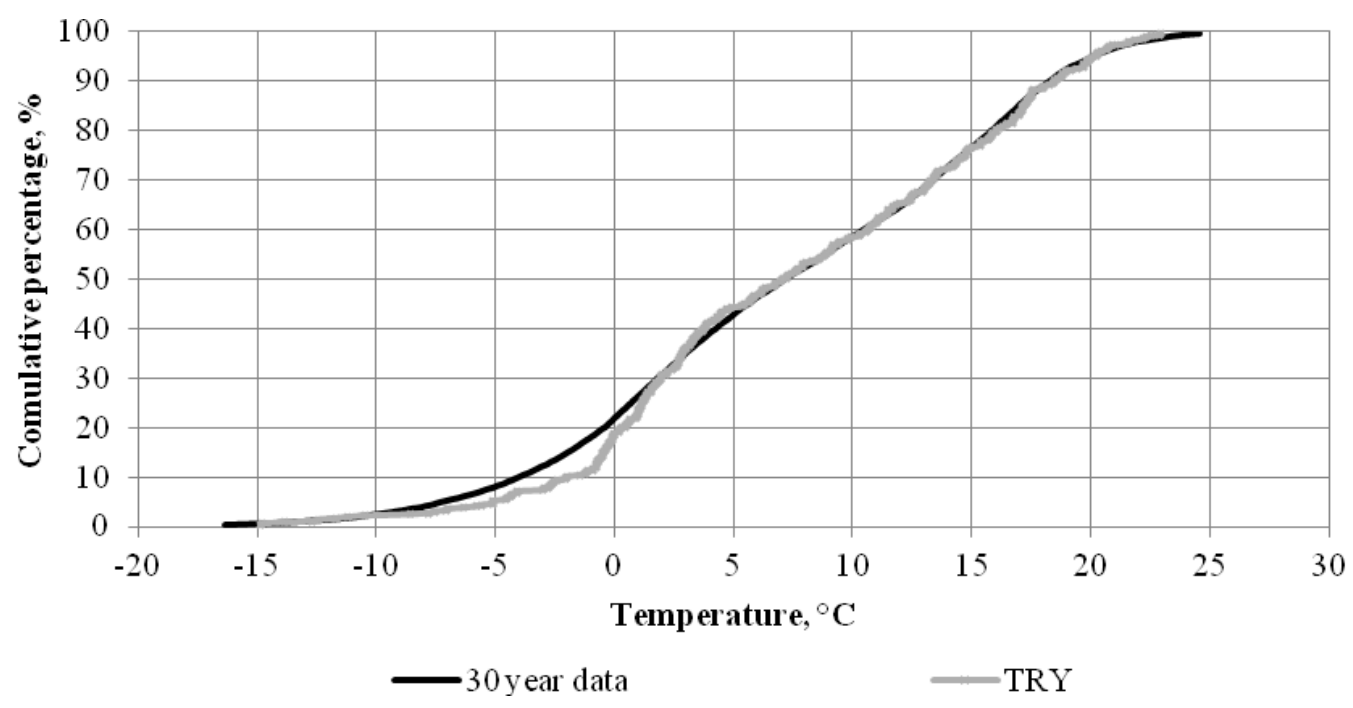

Fig. 3. Comparison of temperature cumulative percentage

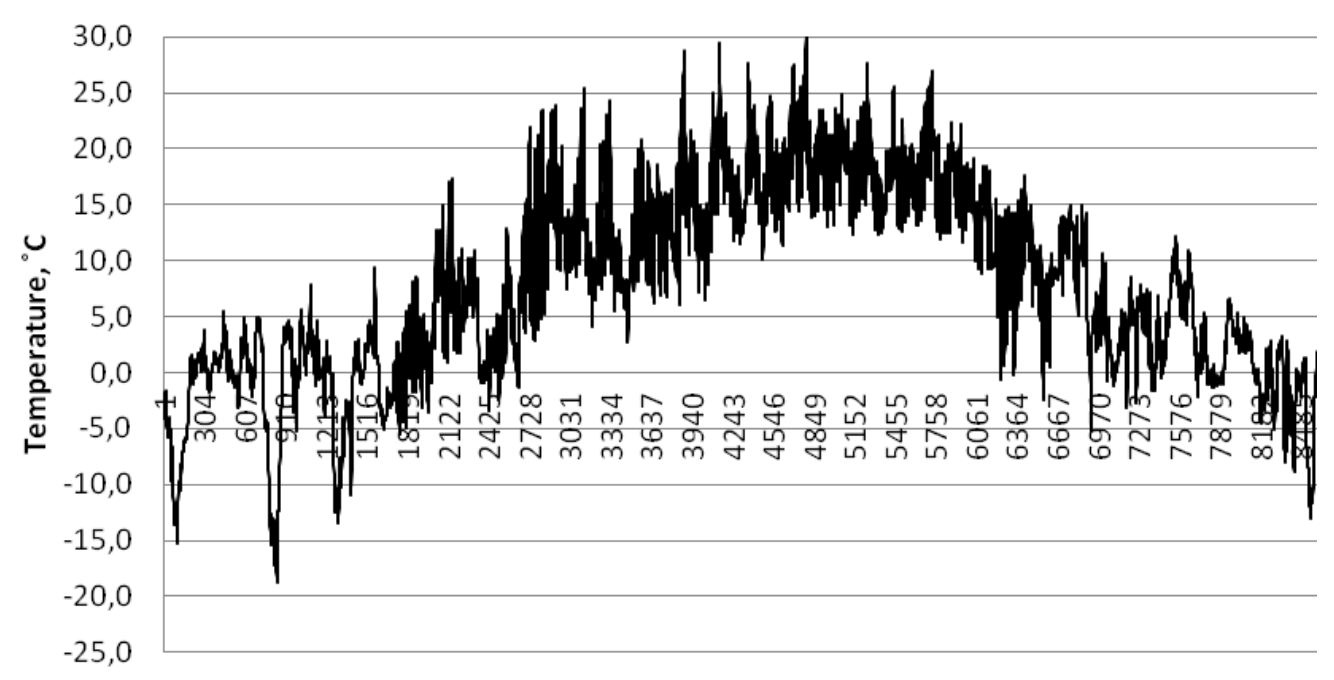

Time from the beginning of January untill the end of December, $h$ Fig. 4. Temperature variation through TRY

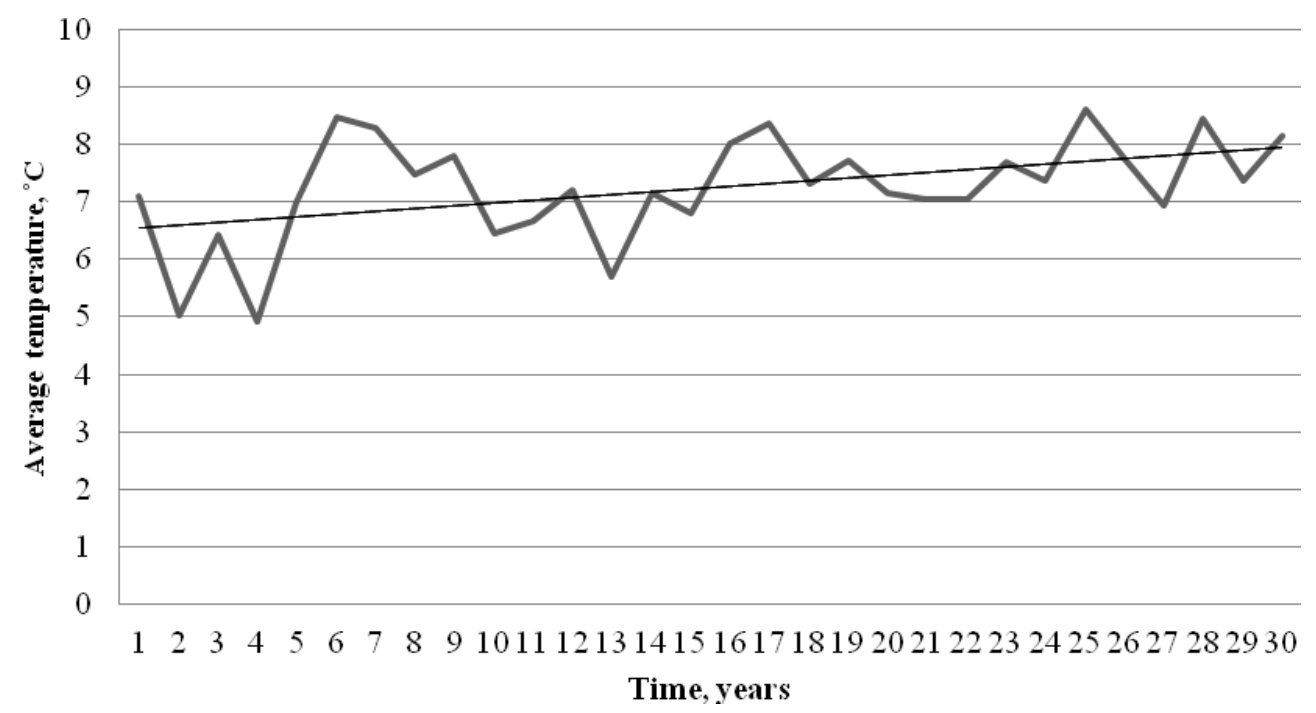

Fig. 5. Average temperature for 30-year period (1984-2013) 
TRY average wind speed values reveal high similarity with 30-year average data (Figure 6) with some deviation in values. The largest observed time difference at $5 \mathrm{~m} \mathrm{~s}^{-1}$ for 170 hours per year, but the total difference for all wind speed values is 851 hour or $9.7 \%$ of all 8,760 hours in a calendar year.

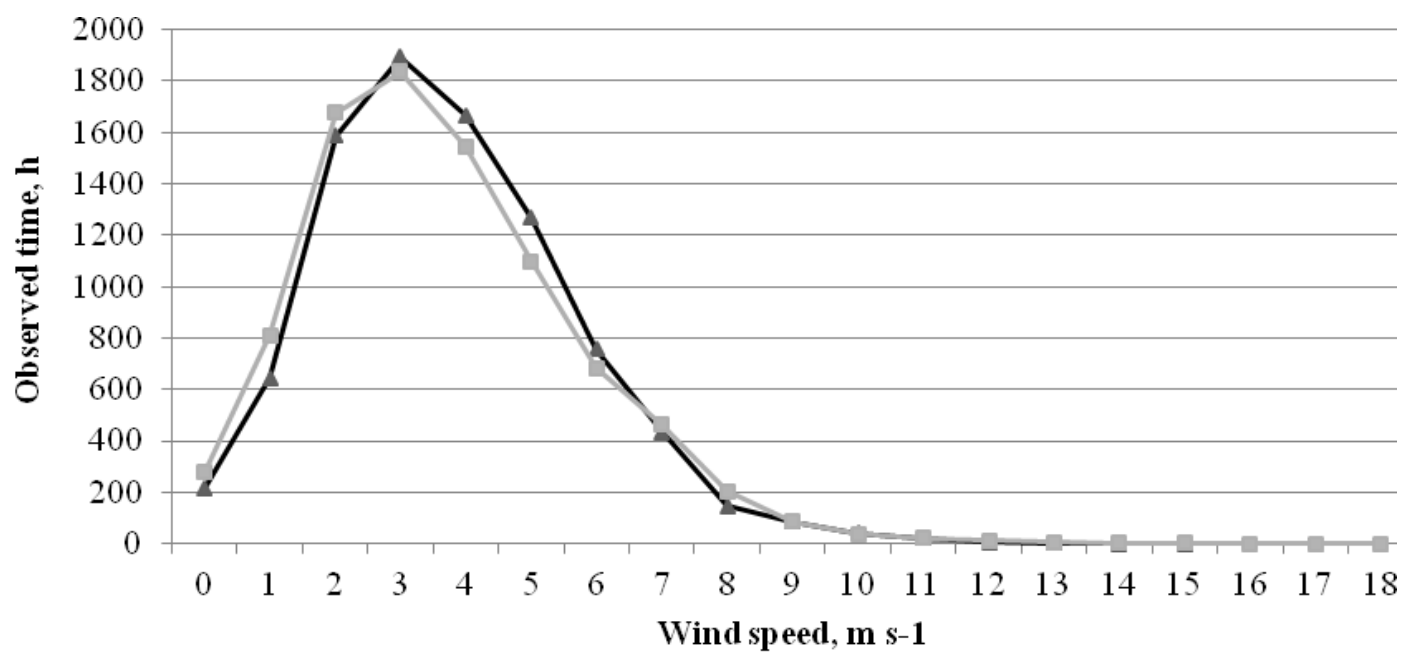

$\longrightarrow$ TMG $\longrightarrow-30$ year average

Fig. 6. Comparison of TRY and 30-year average data wind speed distribution

TRY hourly temperature values reveal high similarity with 30-year hourly temperature values, when their air temperature distribution values are compared (Figure 7). The largest observed time difference for TRY and 30-year average air temperature values is 203 hours at $0{ }^{\circ} \mathrm{C}$. The total observed time difference for air temperature distribution between TRY and 30-year average data values is 1,476 hours or $16.8 \%$ of total year hour values. That is $6.6 \%$ increase of the total observed time difference comparing with TRY of Liepaja [8], and $41.4 \%$ increase comparing with TRY of Aluksne [9].

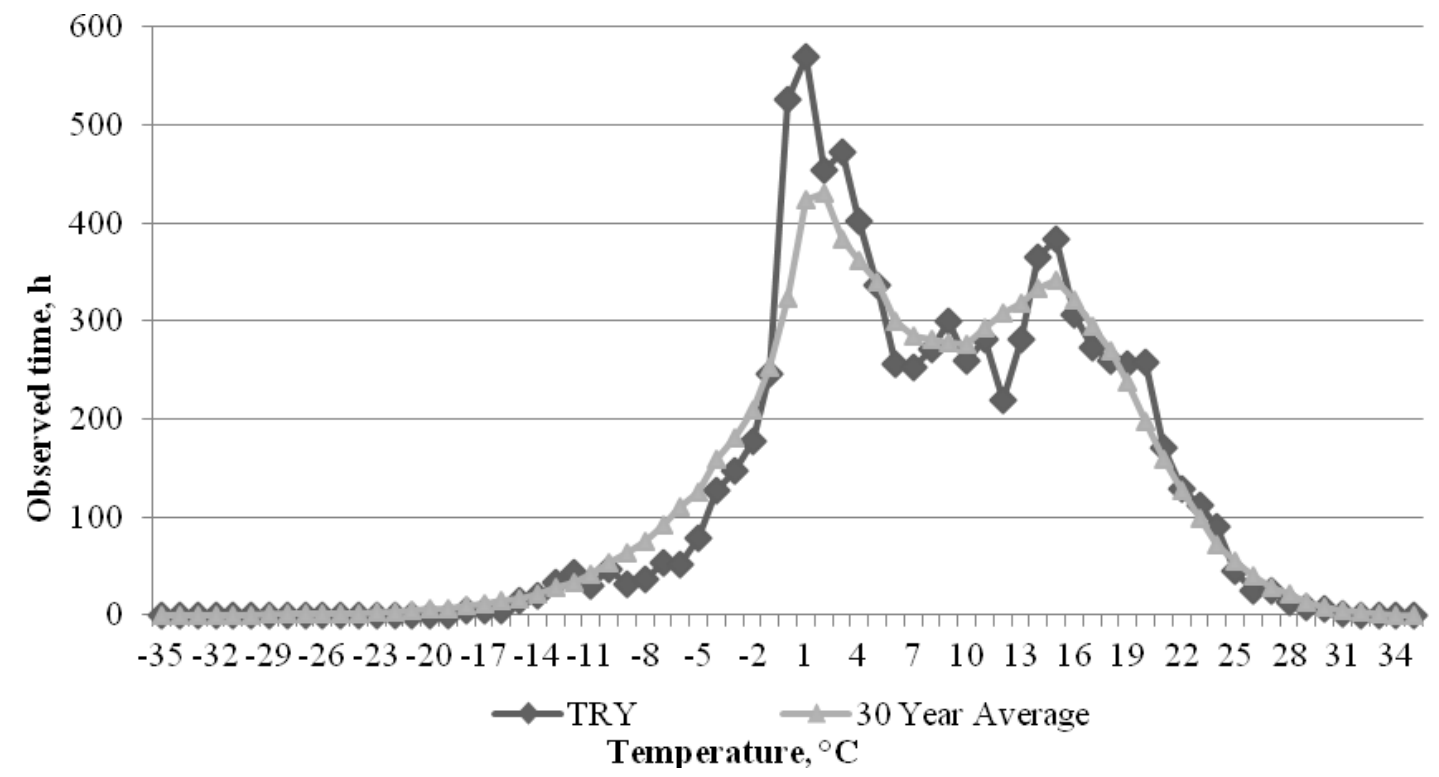

Fig. 7. Comparison of TRY and 30-year average data temperature distribution

A very important result that can be gained from TRY model is temperature and content of a moisture combinations per year. Figure 8 represents how many hours per year each combination can be observed.
The most typical air temperature is $1{ }^{\circ} \mathrm{C}$, it can be observed for 550 hours per year or $6.3 \%$ of all observed air temperature values per year. The most typical content of moisture values is $4 \mathrm{~g} \mathrm{~kg}^{-1}$, it can be 
observed for 1,759 hours per year or $20.1 \%$ of all observed content of moisture values per year. The most typical combination for air temperature and content of moisture is $2{ }^{\circ} \mathrm{C}$ and $4 \mathrm{~g} \mathrm{~kg}^{-1}$, this combination can be observed for 353 hours per year, or $4 \%$ of all possible hourly combinations. Comparing the results with other TRY values, TRY of Riga has the same typical temperature and content of moisture combination as TRY of Liepaja [8], where this combination can be observed for 432 hours or by $22.3 \%$ more than for TRY of Riga. The TRY of Aluksne has the same most typical content of moisture $4 \mathrm{~g} \mathrm{~kg}^{-1}$, but the most typical air temperature is by $2{ }^{\circ} \mathrm{C}$ lower than TRY of Riga $0{ }^{\circ} \mathrm{C}$, and this combination can be observed for 339 hours.

The results can help to determine what kind of HVAC systems are necessary and how many hours per year each of HVAC systems will be running.

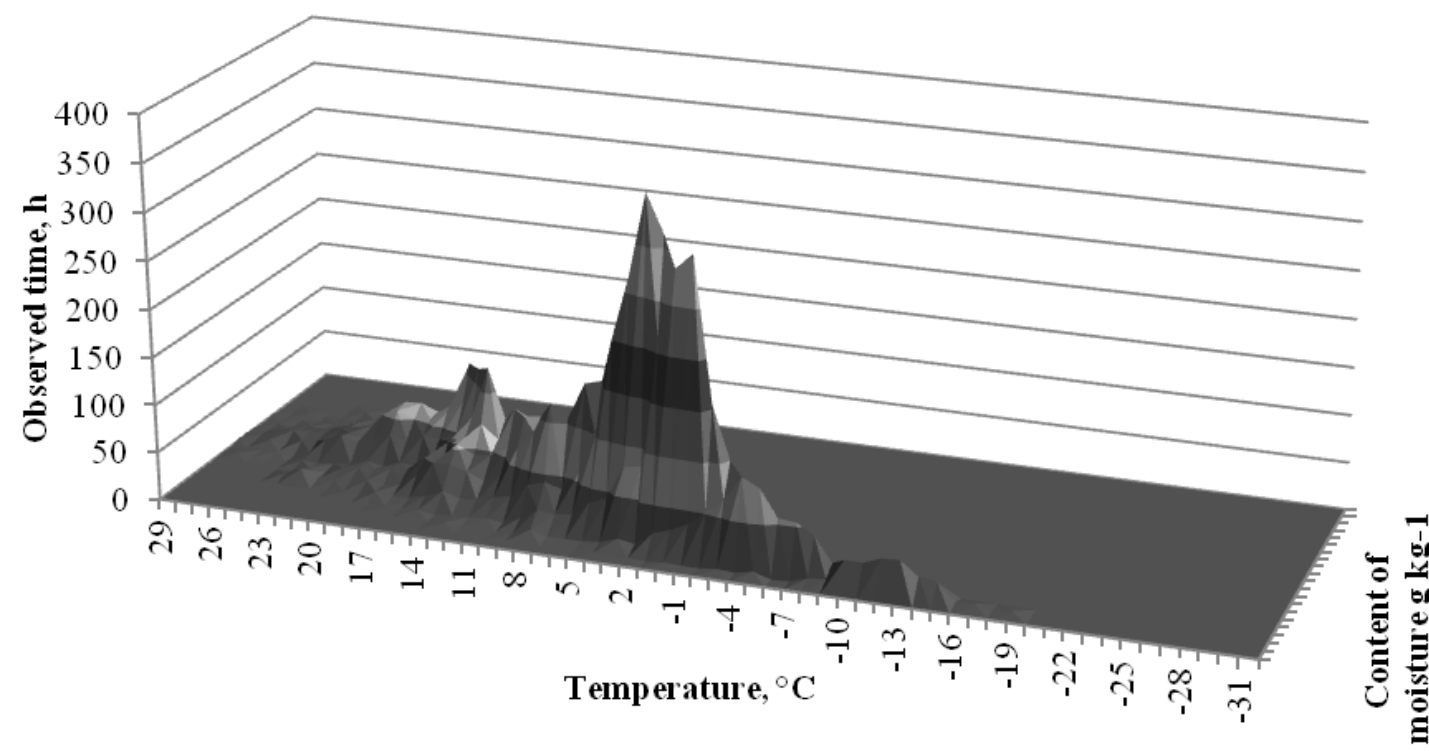

Fig. 8. Temperature and content of moisture combinations for TRY

The highest relative humidity difference in individual months between TRY and 30-year average data is $4 \%$ in February. Average relative humidity value by TRY and 30-year average data is $78 \%$, but there is $1 \%$ difference with the LBN 003-15 value (Table 2).

TABLE 2

Comparison of average monthly relative humidity value (\%) [Source: the authors' construction]

\begin{tabular}{|c|c|c|c|c|c|c|c|c|c|c|c|c|c|}
\hline Month & Jan & Feb & Mar & Apr & May & Jun & Jul & Aug & Sep & Oct & Nov & Dec & Average \\
\hline 30-year average & 85 & 82 & 77 & 70 & 68 & 72 & 73 & 75 & 80 & 83 & 86 & 87 & 78 \\
\hline TRY & 84 & 86 & 76 & 70 & 71 & 69 & 72 & 76 & 77 & 81 & 88 & 88 & 78 \\
\hline LBN 003-15 & 85 & 82 & 79 & 73 & 69 & 72 & 76 & 78 & 81 & 83 & 86 & 86 & 79 \\
\hline
\end{tabular}

Average wind speed value by 30 -year average data is $3.6 \mathrm{~m} \mathrm{~s}^{-1}$ and TRY model has the same average wind speed value. The highest wind speed difference for individual months comparing TRY and 30-year average data is $1 \mathrm{~m} \mathrm{~s}^{-1}$ in December (Table 3).

Comparison of average monthly wind speed values $\left(\mathrm{m} \mathrm{s}^{-1}\right)$ [Source: the authors' construction]

\begin{tabular}{|c|c|c|c|c|c|c|c|}
\hline Month & Jan & Feb & Mar & Apr & May & Jun & Jul \\
\hline 30-year average & 4.2 & 3.9 & 3.8 & 3.5 & 3.4 & 3.2 & 3.1 \\
\hline TRY & 4.5 & 3.9 & 3.5 & 3.5 & 3.4 & 3.3 & 2.7 \\
\hline Month & Aug & Sep & Oct & Nov & Dec & Average \\
\hline 30-year average & 3.1 & 3.4 & 3.7 & 4.0 & 4.1 & 3.6 \\
\hline TRY & 2.8 & 3.0 & 3.7 & 3.8 & 5.1 & 3.6 \\
\hline
\end{tabular}


The average air temperature value by TRY is 7.5 ${ }^{\circ} \mathrm{C}$, but for 30 -year average data, it is $7.2{ }^{\circ} \mathrm{C}$ or $4 \%$ decrease. LBN 003-15 average air temperature is 5.7 ${ }^{\circ} \mathrm{C}$ or $20.8 \%$ difference with 30 -year average data (Table 4). The LBN 003-15 data values have been determined from the period of 1961-1990. Since this period, average air temperature has risen (Figure 5) that can explain the average air temperature difference for LBN 003-15. The largest average air temperature difference is $1.6{ }^{\circ} \mathrm{C}$ in January between TRY and 30-year average data for individual months.

LBN 003-15 has the highest number of heating degree-days (HDD) 3,654 comparing with TRY data
3,249. HDD days are calculated at the inside air temperature $18{ }^{\circ} \mathrm{C}$. LBN 003-15 average air temperature in the heating period is $0.0{ }^{\circ} \mathrm{C}$, but for TRY, it is by $0.9^{\circ} \mathrm{C}$ higher. LBN 003-15 duration of the heating period is 13 days longer than for TRY, it also has the lowest observed minimal temperature and highest maximum observed air temperature. This tendency is also similar for other TRY models in Latvia [8, 9]. The differences in values can be explained with different time periods for measurements of the values.

TABLE 4

Comparison of average temperature values $\left({ }^{\circ} \mathrm{C}\right)$ [Source: the authors' construction]

\begin{tabular}{|c|c|c|c|c|c|c|c|}
\hline Month & Jan & Feb & Mar & Apr & May & Jun & Jul \\
\hline 30-year average & -2.7 & -3.1 & 0.6 & 6.6 & 12.2 & 15.9 & 18.5 \\
\hline TRY & -1.1 & -3.0 & 2.0 & 6.4 & 12.6 & 15.2 & 18.8 \\
\hline LBN 003-15 & -4.7 & -4.3 & -0.6 & 5.1 & 11.4 & 15.4 & 16.9 \\
\hline Month & Aug & Sep & Oct & Nov & Dec & \multicolumn{2}{|c|}{ Average } \\
\hline 30-year average & 17.5 & 12.5 & 7.5 & 2.3 & -1.3 & \multicolumn{2}{|c|}{7.2} \\
\hline TRY & 17.9 & 12.2 & 6.2 & 3.5 & -0.9 & \multicolumn{2}{|c|}{7.5} \\
\hline LBN 003-15 & 16.2 & 11.9 & 7.2 & 2.1 & -2.3 & \multicolumn{2}{|c}{5.7} \\
\hline
\end{tabular}

Climate parameter comparison [Source: the authors' construction]

\begin{tabular}{|c|c|c|}
\hline Parameter & TRY & LBN 003-15 \\
\hline Maximum temperature, ${ }^{\circ} \mathrm{C}$ & 30.1 & 32.2 \\
\hline Minimum temperature, ${ }^{\circ} \mathrm{C}$ & -18.7 & -31.0 \\
\hline Duration of heating period, days & 190 & 203 \\
\hline Average air temperature in heating period, ${ }^{\circ} \mathrm{C}$ & 0.9 & 0.0 \\
\hline Number of heating degree days (HDD) & 3249 & 3654 \\
\hline
\end{tabular}

\section{Conclusions}

In this research, TRY of Riga was generated based on 30-year meteorological data (1984-2013). The research results show that TRY values reveal high similarity with 30 -year average data, but there is a deviation from LBN 003-15 data. The results imply that LBN 003-15 values are not up to date with today's climate situation. The average air temperature has been rising and leading to climate changes. As LBN 003-15 is the only legitimate source for climate parameters and it shows deviation from newer climate parameters, changes should be made in LBN 003-15 climate parameter values to represent more recent climate situation.

TRY provides hourly values of climate parameters that can be used for HVAC system analysis. If LBN 003-15 would be updated with hourly climate parameters, it would be a legitimate source of climate parameters for HVAC system calculations.

Results suggest that future research is necessary to be done for all cities of Latvia that have been included in LBN 003-15, and the results are necessary to be updated in LBN.

\section{References}

1. David, M., Adelard, L., Lauret, P., Garde, F. A method to generate Typical Meteorological Years from raw hourly climatic databases. Building and Enviroment, 2010, No. 45, p. 1722-1732.

2. Ebrahimpour, A., Maerefat M. A method for generation of typical meteorological year. Energy Conversion and Managment, 2010, No 51, p. 410-417.

3. Hall, I.J., Prairie, R.R., Anderson, H.E., Boes, E.C. Generation of a typical meteorological year. Proceedings of the 1978 Annual Meeting of the American Section of the International Solar Energy Society, 1987, p.669-671.

4. Latvijas Republika. Kultüra [online 04.11.2017]. http://old.pvg.edu.lv/datori/konkursi/2011_web/Raivis_Pastars/kultura.html (In Latvian). 
5. Latvijas Valsts Standarts (Latvia State Standard). LVS EN ISO 15927-4. Ēku hidrotermiskie raksturlielumi. Klimatisko raksturlielumu aprēḳināšana un izteikšana. 4. daḷa: Ikstundas dati apkures un dzesēšanas ikgadējā enerǵijas patēriṇa novērtēšanai. (Hygrothermal performance of buildings - Calculation and presentation of climatic - Part 4: Hourly data for assessing the annual energy use for heating and cooling), 2005. 5 p.

6. Ministru kabineta noteikumi Nr. 338. Noteikumi par Latvijas būvnormatīvu 003-15 "Būvklimatalogija” (Latvian Building Code 003-15 “Construction climatology") [online 10.10.2017.]. http://likumi.lv/ta/id/275013-noteikumi-par-latvijas-buvnormativu-lbn003-15-buvklimatologija- (in Latvian).

7. Pauls, R. Klimatologiskie dati ēkas energíjas patēriņa novērtēšanai (Climatic data for assessing building energy consumption). Master thesis (in Latvian). Riga: Riga Technical University, 2011. 40 p

8. Ruduks, M., Lešinskis, A. Generation of a Test Reference Year for Liepāja, Latvia. Proceedings of annual 22nd International Scientific Conference Research for Rural Development 2016, 2016, Vol. 1, No. 1, p. 175-181.

9. Ruduks, M., Lešinskis, A. Generation of a Test Reference Year for Alūksne, Latvia. Proceedings of the Latvia University of Agriculture, 2015, Vol. 33, No. 1, p. 46-54.

10. Skeiker K., Ghani B.A. Advance software tool for the creation of a typical meteorological year. Energy Conversion and Managment, 2008, No 49, p. 2581-2587.

11. Skeiker, K. Generation of a typical meteorological year for Damascus zone using the Filkenstein-Schafer statistical method. Energy Conversion and Management, 2004, Vol. 45, p. 99-112.

12. Zarin̦š, M. Klimata datu izvēle gaisa kondicionēšanas jaudas aprēķinam (Climate data for air conditioning power calculations). Bachelor thesis (in Latvian). Jelgava: Latvia University of Agriculture, 2001. 59 p 